Pol. J. Food Nutr. Sci., 2021, Vol. 71, No. 1, pp. 21-28

On-line ISSN: 2083-6007

Print ISSN: $1230-0322$

DOI: $10.31883 /$ pjfns/131061

http://journal.pan.olsztyn.pl

Original article

Section: Food Quality and Functionality

\title{
Elicitation with Sodium Silicate and Iron Chelate Affects the Contents of Phenolic Compounds and Minerals in Buckwheat Sprouts
}

\author{
Henryk Dębski ${ }^{\circledR}$, Wiestaw Wiczkowski ${ }^{2}$, Dorota Szawara-Nowak ${ }^{2} \odot$, Marcin Horbowicz $^{1 *} \odot$ \\ ${ }^{I}$ Institute of Biological Sciences, Siedlce University of Natural Sciences and Humanities, Prusa 14, 08-110 Siedlce, Poland \\ ${ }^{2}$ Department of Chemistry and Biodynamics of Food, Institute of Animal Reproduction and Food Research \\ of the Polish Academy of Sciences, Tuwima 10, 10-748 Olsztyn, Poland
}

Key words: Fagopyrum esculentum, common buckwheat, flavonoids, phenolic acids, iron, silicon

\begin{abstract}
The study concerned the effect of elicitors on the contents of free flavonoids and phenolic acids, as well as their esters and glycosides, and contents of minerals in 7-day sprouts of common buckwheat. An aqueous solution containing a mixture of sodium silicate and Fe-EDTA (SIL-Fe) was compared with the same concentration of sodium silicate alone (SIL) and water (control). Phenolic compounds were analysed using an HPLC-MS/MS apparatus equipped with an ion-trap mass spectrometer, and analyses were conducted by multiple reaction monitoring of selected negative ions. The contents of macro- and microelements in sprouts were determined by the ICP-AES method, after sample mineralization in a mixture of $\mathrm{HNO}_{3}$ and $\mathrm{H}_{2} \mathrm{O}_{2}$. The study showed that SIL-Fe influenced the accumulation of individual phenolics in buckwheat sprouts in different ways. Among the major flavonoids in the buckwheat sprouts treated with SIL-Fe, the content of free forms and esters of (-)-epicatechin and glycosides of quercetin as well as the total content of flavonoids decreased. Elicitation of buckwheat sprouts with SIL and SIL-Fe reduced the contents of calcium, potassium, copper, and zinc; however, the SIL-Fe treatment caused a 5-fold increase in iron content and a 2-fold increase in silicon content. The ratio of total flavonoids to the iron content of SIL-Fe-treated sprouts was 11.5 , which was substantially lower than in the control, where it reached 64 . The results of this study indicate that it is possible to produce buckwheat sprouts with a high content of flavonoids and fortified with iron, which may increase the availability of this element.
\end{abstract}

\section{INTRODUCTION}

Sprouts of various plant species are recognised as an important source of protein, mineral, dietary fiber, and vitamins in the human diet [Benincasa et al., 2019]. Germination has been reported to increase the macro- and microelements availability and also to significantly reduce the phytic acid content [Mbithi-Mwikya et al., 2000; Sokrab et al., 2012]. Compared with the seeds of common buckwheat (Fagopyrum esculentum Moench), the sprouts have a much higher content of phenolics [Kim S.-L. et al., 2004; Kim S.-J. et al., 2008; Kreft, 2016; Wijngaard \& Arendt, 2006]. They are also rich in flavonoids representing several classes, i.e. flavonols, flavones, flavan-3-ols, and anthocyanins [Wiczkowski et al., 2014], and in phenolic acids [Horbowicz et al., 2015]. Buckwheat sprouts also contain derivatives of trans-cinnamic acid and benzoic acid [Wiczkowski et al., 2016], while rapid accumulation of phenolic compounds is observed during their growth [Kim et al., 2008; Koyama et al., 2013; Terpinc et al., 2016].

Elicitation is a method that effectively increases the accumulation of secondary metabolites in plants [Baenas et al., 2014; Horbowicz et al., 2015; Park et al., 2017, 2019; Ruiz-Garcia \& Gómez-Plaza, 2013]. Biotic elicitors have been

\footnotetext{
* Corresponding Author e-mail: mhorbowicz@uph.edu.pl (Prof. M. Horbowicz).
}

shown to enhance the accumulation of flavonoids and other phenolic compounds in buckwheat sprouts [Park et al., 2017, 2019]. Also sodium silicate affected the antioxidant system of ryegrass by enhancing phenolics production and antioxidant enzyme activation [Ribera-Fonseca et al., 2018]. Silicon application increased phenolic compound contents in cucumber [Fawe et al., 1998] and maize [Kidd et al., 2001]. However, Chérif et al. [1994] reported that silicon had no effect on phenolic contents of plants in the absence of pathogen infection. On the other hand, Rogalla \& Römeheld [2002] reported a decrease in the activity of phenylalanine ammonia-lyase (PAL) in Si-supplemented plants, and a decrease in phenolics content. They suggested that the decrease in phenolics content was caused by the mechanism of stress reduction through the formation of Si complexes with phenol moiety.

Mineral nutrient availability, uptake, and transport in plants are affected by a number of factors resulting in complex interactions between the elements [Marschner, 1980]. For instance, calcium is highly competitive with magnesium and potassium, while an excess $\mathrm{Ca}$ content in soil causes a deficiency of $\mathrm{Fe}, \mathrm{B}$, $\mathrm{Mn}, \mathrm{Mg}$, and $\mathrm{K}$ in plants. Silicon influences the accumulation of mineral nutrients in various plant species, and this influence depends on species examined as well as conditions of its growth [Greger et al., 2018]. Si was added to the nutrient solution to diminish the uptake of Ca by rice plants [Ma \& Takahashi, 1993], and Zn content in leaves of maize [Kaya et al., 2009]. 
Silicon in soil was reported to have a major impact on the contents of calcium and microelements in grasses. A pot experiment with increased levels of silicon demonstrated a significant decline of calcium, manganese, iron, cobalt, copper, and zinc contents in leaf blades of common reed [Brackhage et al., 2013].

The germination of crucifer and legume seeds in the presence of Fe generated a considerable increase in the content of this element in sprouts, but their biomass accumulation slightly decreased [Przybysz et al., 2016]. The cited authors have also shown that a higher Fe content increased the activity of antioxidative enzymes and contents of phenolic compounds.

Phenolics, as bioactive compounds occurring in plants and plant products, can play a beneficial role in human health, including the prevention of oxidative stress-related diseases and inflammatory conditions [Cory et al., 2018; Cvejic et al., 2018]. In turn, their cardioprotective properties are related to their antioxidant effect. In recent years, polyphenols have also been tested for their antiatherosclerotic properties [Santhakumar et al., 2018].

Although flavonoids have many important properties for human health, they cannot be supplied in a diet in excessive quantities. This is because they can inhibit intestinal absorption of various elements, including the nonheme type of iron [Thankachan et al., 2008]. Iron deficiency is one of the most extensive health disorders in the world, which may contribute to anemia development in a significant part of the global population [Stoltzfus et al., 2004]. This deficiency still affects about a quarter of women and children worldwide [Cappellini et al., 2020]. A high level of polyphenols is one of the causes of low absorption of iron by the human organism [Zijp et al., 2000]. Nonheme iron is the major form of this element in plant foods and supplements. According to Hurrell et al. [1999], the excess consumption of tea or cocoa can significantly decrease the absorption of nonheme iron. Flavonoids can also inhibit intestinal heme iron absorption [Ma et al., 2011]. Therefore, flavonoid-rich food and beverages should not be consumed together with high-Fe meals. This was an important reason for undertaking this study, the results of which may show the way to counteract the phenomenon of low iron bioavailability.

Therefore, the main research hypothesis advanced in this study was whether the presence of easily assimilable iron affects the content of phenolic compounds. Since iron was used in a mixture with sodium silicate, a separate set of sprouts was treated only with silicate for comparison. The detailed objectives of this study were to quantify free forms, esters, and glycosides of flavonoids and phenolic acids as a response to silicon and iron applied during germination and 7-day growth of common buckwheat sprouts. Another aim of the investigation was to determine the contents of iron and silicon and other macro- and microelements in these sprouts.

\section{MATERIAL AND METHODS}

\section{Plant material}

Seeds of common buckwheat (cv. Hruszowska) were soaked at $24^{\circ} \mathrm{C}$ in distilled water for $4 \mathrm{~h}$. Initially, seeds without a seed coat were disinfected with $70 \%(v / v)$ ethanol for $1 \mathrm{~min}$, and then with $2 \%$ sodium hypochlorite for $2 \mathrm{~min}$, rinsed once in $0.01 \mathrm{~N} \mathrm{HCl}$ and 3 times with distilled water. The disinfected seeds were placed on a layer of sterilized and moist cotton gauze stretched over an open $330-\mathrm{mL}$ jar. In the next six days, the seeds and sprouts were soaked in distilled water (control) or elicitor solutions (SIL, SIL-Fe). The soaking lasting 15 min was carried out twice each day, at 9 am and $5 \mathrm{pm}$. After each treatment, the seeds were placed back on the gauze layer. The sprouts were grown under exposure to $100-120 \mu \mathrm{mol} /\left(\mathrm{m}^{2} \cdot \mathrm{s}\right)$ photosynthetically active radiation produced by high-pressure sodium lamps at $20 \pm 1^{\circ} \mathrm{C}$ (day, $16 \mathrm{~h}$ ) and $16 \pm 2{ }^{\circ} \mathrm{C}$ (night, $8 \mathrm{~h}$ ). On the seventh day, the obtained sprouts were collected, cut into $2-3 \mathrm{~mm}$ pieces, freeze-dried in a laboratory freeze dryer (Alpha 1-2 LDplus, Martin Christ, Osterode am Harz, Germany) for 48 h, and used for analyses of flavonoids and phenolic acids, as well as micro- and macroelements.

\section{Elicitor composition}

The elicitors used in the study were solutions containing sodium metasilicate $\left(\mathrm{Na}_{2} \mathrm{SiO}_{3}\right.$; $\left.\mathrm{SIL}\right)$, and a mixture of sodium metasilicate and Fe-EDTA chelate (SIL-Fe, trade mark Optysil, Intermag, Olkusz, Poland). Buckwheat seeds or sprouts were immersed in $50 \mathrm{~mL}$ of distilled water (control), or in $50 \mathrm{~mL}$ of the solutions containing sodium metasilicate with a concentration of $4 \mathrm{mM}$ (SIL), or with the Optysil, i.e. a mixture of Fe-EDTA and sodium metasilicate, $0.5 \mathrm{mM} \mathrm{Fe}$ and $4 \mathrm{mM}$ of $\mathrm{Na}_{2} \mathrm{SiO}_{3}$ (SIL-Fe), respectively.

\section{Analyses of free, esters and glycosides of flavonoids and phenolic acids}

Sprout samples were analyzed with HPLC-MS/MS to determine various forms of phenolic acids and flavonoids. The profile and content of phenolic acids and flavonoids were determined according to the method of Płatosz et al. [2020]. Briefly, a crude extract was obtained from freeze-dried sprout samples with a mixture of methanol, water, and formic acid. The extraction was repeated five times, and from the obtained crude extracts free phenolic acids and flavonoids were isolated with diethyl ether after adjusting extract to $\mathrm{pH} 2$ with $6 \mathrm{M} \mathrm{HCl}$. After the isolation of free forms, esters were hydrolyzed at room temperature with $4 \mathrm{M} \mathrm{NaOH}$, and glycosides in the residues were hydrolyzed with $6 \mathrm{M} \mathrm{HCl}$. The released by hydrolysis free forms of phenolic compounds were extracted with diethyl ether. The obtained ether extracts were evaporated to dryness under stream of nitrogen and the residue was dissolved in $80 \%(v / v)$ methanol. The HPLC system used was equipped with a HALO C18 column $(2.7 \mu \mathrm{m}$ particles, $0.5 \times 50 \mathrm{~mm}$, Eksigent, Vaughan, Canada) which was kept at $45^{\circ} \mathrm{C}$, and the eluent flow was $15 \mu \mathrm{L} / \mathrm{min}$. The eluent was a mixture of $\mathrm{A}$ (water/formic acid; $99.05 / 0.95 ; v / v$ ) and $\mathrm{B}$ (acetonitrile/formic acid, 99.05/0.95, v/v). The gradient was used as follows: $5 \%$ B for $0.1 \mathrm{~min}, 5-90 \% \mathrm{~B}$ in $1.9 \mathrm{~min}, 90 \% \mathrm{~B}$ for $0.5 \mathrm{~min}, 90-5 \% \mathrm{~B}$ in $0.2 \mathrm{~min}$, and $5 \% \mathrm{~B}$ for $0.3 \mathrm{~min}$. For the HPLC-MS/MS analysis, a QTRAP 5500 ion trap mass spectrometer (AB SCIEX, Vaughan, Canada) was applied. Qualitative and quantitative analyses were conducted in the negative mode by multiple reaction monitoring of selected ions. The following flavonoids (free, esters and glycosides) were analyzed: (-)-epicatechin, luteolin, orientin, vitexin, api- 
genin, naringenin, kaempferol, iso-rhamnetin, and quercetin. Derivatives (free, esters, glycosides) of the following phenolic acids were analyzed as well: 4-hydroxybenzoic, caffeic, sinapic, $p$-coumaric, ferulic, syringic, and chlorogenic acids.

\section{Determination of macro- and microelements}

The contents of macro- and microelements were determined by the ICP-AES method using an Optima 8300 ICP-AES/OES spectrometer (Perkin Elmer, Waltham, MA, USA), after sample mineralization in a mixture of concentrated $\mathrm{HNO}_{3}$ and $20 \% \mathrm{H}_{2} \mathrm{O}_{2}(3: 1)$ in a microwave system for $2 \mathrm{~h}$ [Barnes \& Debrah, 1997].

\section{Statistical analysis}

Analyses of sprout tissue were performed in three replicates. The analysis of variance (one-way ANOVA) and Tukey's post hoc test were used to check the significance of differences. Calculations were performed using Statistica 12PL software (StatSoft, Tulsa, OK, USA).

\section{RESULTS AND DISCUSSION}

The use of iron chelate (SIL-Fe) and sodium silicate (SIL) during the germination and growth of buckwheat sprouts caused various changes in the content of individual phenolic compounds (Tables 1-5). Moreover, the use of iron chelate (SIL-Fe) resulted in about 20\% lower fresh and dry matter contents of the buckwheat sprouts compared to those grown under control conditions (data not shown). Inhibition of growth under the influence of iron was previously demonstrated in the sprouts of crucifers [Przybysz et al., 2016].

The quantitatively major flavonoid in 7-day buckwheat sprouts was (-)-epicatechin, which occurred mainly in the free form, representing more than $90 \%$ of its total content (Table 1). Regarding the content, the second group of flavonoids were their glycosides. Among them, quercetin glycosides appeared in the highest contents. However, (-)-epicatechin, apigenin, luteolin, and iso-rhamnetin did not appear as glycosides. The (-)-epicatechin content was many times higher compared to other flavonoids (Tables 1, 2, and 3). This confirms our earlier report in which 7-day sprouts of four buckwheat cultivars contained 3900-5400 $\mu \mathrm{g} / \mathrm{g}$ dry weight (DW) (-)-epicatechin in cotyledons and 1000-1300 $\mu \mathrm{g} / \mathrm{g}$ DW in hypocotyl [Wiczkowski et al., 2014]. However, in other studies, in 10-day-old sprouts of Korean buckwheat, the (-)-epicatechin content was much lower, and reached only $455 \mu \mathrm{g} / \mathrm{g}$ DW [Park et al., 2017]. Lower than presented here contents of (-)-epicatechin in buckwheat sprouts were also noted by Park et al. [2019]. On the other hand, similar epicatechin contents were found in 3-month-old leaves, stems, and roots of buckwheat [Uddin et al., 2013].

A high (-)-epicatechin content is beneficial because the antioxidant activity of this flavonoid is higher than that of rutin, which is the major phenolic compound of buckwheat seeds [Watanabe, 1998]. Results from human trials indicate that (-)-epicatechin acts as an antioxidant both directly as a scavenger of free radicals and indirectly as a modulator of superoxide dismutase and glutathione peroxidase [Simos et al., 2012]. It can also modulate macronutrient metabolism in normal and overweight subjects [Gutiérrez-Salmeán et al., 2014].
TABLE 1. The contents of major flavonoids (free and released from ester and $O$-glycoside forms) in buckwheat sprouts $(\mu \mathrm{g} / \mathrm{g} \mathrm{DW})$ treated with elicitors during growth.

\begin{tabular}{|c|c|c|c|c|}
\hline Treatment & Free forms & Esters & $O$-glycosides & Total \\
\hline \multicolumn{5}{|c|}{ (-)-Epicatechin } \\
\hline Control & $3529 \pm 78^{a}$ & $77.05 \pm 3.25^{\mathrm{b}}$ & nd & $3606 \pm 81^{\mathrm{a}}$ \\
\hline SIL-Fe & $2674 \pm 59^{b}$ & $33.19 \pm 2.18^{c}$ & nd & $2707 \pm 61^{b}$ \\
\hline SIL & $2652 \pm 45^{b}$ & $132.5 \pm 2.99^{a}$ & nd & $2784 \pm 48^{b}$ \\
\hline \multicolumn{5}{|c|}{ Quercetin } \\
\hline Control & $81.23 \pm 4.11^{\mathrm{a}}$ & $96.33 \pm 5.23^{b}$ & $749.3 \pm 11.5^{\mathrm{a}}$ & $926.9 \pm 20.6^{\mathrm{a}}$ \\
\hline SIL-Fe & $93.45 \pm 3.89^{\mathrm{a}}$ & $80.33 \pm 6.45^{b}$ & $511.2 \pm 16.2^{\mathrm{c}}$ & $685.0 \pm 26.5^{c}$ \\
\hline SIL & $59.65 \pm 2.56^{b}$ & $143.0 \pm 4.89^{\mathrm{a}}$ & $590.4 \pm 8.9^{b}$ & $793.1 \pm 16.4^{b}$ \\
\hline \multicolumn{5}{|c|}{ Orientin } \\
\hline Control & $132.2 \pm 4.1^{\mathrm{b}}$ & $106.6 \pm 4.9^{c}$ & nd & $238.8 \pm 9.0^{\mathrm{b}}$ \\
\hline SIL-Fe & $133.1 \pm 3.2^{\mathrm{b}}$ & $141.3 \pm 4.8^{\mathrm{b}}$ & nd & $274.4 \pm 7.0^{\mathrm{b}}$ \\
\hline SIL & $171.2 \pm 5.4^{\mathrm{a}}$ & $189.6 \pm 6.6^{\mathrm{a}}$ & nd & $360.8 \pm 7.8^{\mathrm{a}}$ \\
\hline \multicolumn{5}{|c|}{ Luteolin } \\
\hline Control & $6.62 \pm 0.22^{a}$ & $9.70 \pm 0.33^{\mathrm{a}}$ & $99.17 \pm 2.99^{b}$ & $115.5 \pm 3.5^{b}$ \\
\hline SIL-Fe & $6.17 \pm 0.17^{a}$ & $5.28 \pm 0.25^{b}$ & $93.71 \pm 3.11^{\mathrm{b}}$ & $105.2 \pm 3.5^{b}$ \\
\hline SIL & $6.47 \pm 0.11^{\mathrm{a}}$ & $6.35 \pm 0.33^{b}$ & $151.6 \pm 4.4^{\mathrm{a}}$ & $164.4 \pm 4.8^{\mathrm{a}}$ \\
\hline \multicolumn{5}{|c|}{ Vitexin } \\
\hline Control & $47.37 \pm 2.01^{\mathrm{b}}$ & $52.02 \pm 2.09^{\mathrm{b}}$ & nd & $99.40 \pm 5.10^{\mathrm{a}}$ \\
\hline SIL-Fe & $72.25 \pm 2.89^{\mathrm{a}}$ & $42.19 \pm 1.99^{\mathrm{b}}$ & nd & $114.4 \pm 4.9^{a}$ \\
\hline SIL & $62.35 \pm 3.11^{\mathrm{a}}$ & $62.92 \pm 1.33^{\mathrm{a}}$ & nd & $125.3 \pm 3.1^{\mathrm{a}}$ \\
\hline
\end{tabular}

Results are shown as mean \pm standard deviation $(n=3)$. Means marked with the same letter are statistically insignificant at $\mathrm{P}>0.05$ (post hoc Tukey's test). Comparisons were made within each column, for each flavonoid separately. nd - not detected; SIL-Fe - sodium metasilicate and Fe-EDTA chelate; SIL - sodium metalsilicate; DW - dry weight.

Besides (-)-epicatechin, derivatives of quercetin, orientin, vitexin, luteolin, apigenin, kaempferol, naringenin, and iso-rhamnetin were found in seven-day buckwheat sprouts (Tables 2 and 3). Similar composition of these flavonoids was found in 4-day sprouts of buckwheat by Terpinc et al. [2016]. Their results showed that the total content of C-glycosides of luteolin and apigenin exceeded the content of flavonols: quercetin-3-O-rutinoside and quercetin-3-O-sophoroside. In general, the contents of individual phenolics significantly increased during sprout growth from 6 to 10 days after germination [Kim et al., 2008]. In turn, Koyama et al. [2013] have shown that the highest content of flavonoids in buckwheat sprouts was reached on day 6 of their cultivation. The results of the analysis of flavonoids in buckwheat sprouts are influenced by the fact that their content in cotyledons is many times higher than in hypocotyl and roots [Horbowicz et al., 2015]. The mass proportions of these morphological parts change rapidly during sprout growth. Therefore, it is likely that the changing proportion of individual morphological parts of the sprout may be a major factor affecting its composition. 
TABLE 2. The contents of minor flavonoids (free and released from ester and $O$-glycoside forms) in buckwheat sprouts $(\mu \mathrm{g} / \mathrm{g} \mathrm{DW})$ treated with elicitors during growth.

\begin{tabular}{|c|c|c|c|c|}
\hline Treatment & Free forms & Esters & $O$-glycosides & Total \\
\hline \multicolumn{5}{|c|}{ iso-Rhamnetin } \\
\hline Control & $47.56 \pm 2.10^{\mathrm{b}}$ & nd & nd & $47.56 \pm 2.10^{b}$ \\
\hline SIL-Fe & $109.1 \pm 4.4^{\mathrm{a}}$ & nd & nd & $109.1 \pm 4.4^{\mathrm{a}}$ \\
\hline SIL & $24.36 \pm 1.25^{\mathrm{c}}$ & nd & nd & $24.36 \pm 1.25^{\mathrm{c}}$ \\
\hline \multicolumn{5}{|c|}{ Apigenin } \\
\hline Control & $4.31 \pm 0.20^{\mathrm{a}}$ & $10.32 \pm 0.22^{\mathrm{a}}$ & $34.46 \pm 1.22^{\mathrm{a}}$ & $49.09 \pm 1.64^{\mathrm{a}}$ \\
\hline SIL-Fe & $3.37 \pm 0.17^{\mathrm{a}}$ & $7.70 \pm 0.16^{\mathrm{b}}$ & $23.91 \pm 0.99^{\mathrm{b}}$ & $34.97 \pm 1.32^{b}$ \\
\hline SIL & $1.70 \pm 0.08^{b}$ & $7.44 \pm 0.13^{\mathrm{b}}$ & $39.07 \pm 1.11^{\mathrm{a}}$ & $48.21 \pm 1.32^{\mathrm{a}}$ \\
\hline \multicolumn{5}{|c|}{ Naringenin } \\
\hline Control & $2.92 \pm 0.10^{\mathrm{b}}$ & $1.25 \pm 0.06^{\mathrm{a}}$ & $1.58 \pm 0.11^{\mathrm{b}}$ & $5.75 \pm 0.27^{b}$ \\
\hline SIL-Fe & $3.34 \pm 0.09^{b}$ & $1.39 \pm 0.08^{\mathrm{a}}$ & $4.79 \pm 0.25^{\mathrm{a}}$ & $9.53 \pm 0.42^{\mathrm{a}}$ \\
\hline SIL & $4.84 \pm 0.09^{\mathrm{a}}$ & $1.17 \pm 0.05^{\mathrm{a}}$ & $4.59 \pm 0.18^{\mathrm{a}}$ & $10.60 \pm 0.32^{\mathrm{a}}$ \\
\hline \multicolumn{5}{|c|}{ Kaempferol } \\
\hline Control & nd & $1.30 \pm 0.09^{\mathrm{a}}$ & $4.19 \pm 0.11^{\mathrm{a}}$ & $5.49 \pm 0.20^{\mathrm{a}}$ \\
\hline SIL-Fe & nd & $1.41 \pm 0.05^{\mathrm{a}}$ & $3.50 \pm 0.08^{\mathrm{a}}$ & $4.91 \pm 0.13^{a}$ \\
\hline SIL & nd & $0.25 \pm 0.03^{\mathrm{b}}$ & $3.31 \pm 0.07^{\mathrm{a}}$ & $3.55 \pm 0.11^{\mathrm{b}}$ \\
\hline
\end{tabular}

Results are shown as mean \pm standard deviation $(n=3)$. Means marked with the same letter are statistically insignificant at $\mathrm{P}>0.05$ (post hoc Tukey's test). Comparisons were made within each column, for each flavonoid separately. nd - not detected; SIL-Fe - sodium metasilicate and Fe-EDTA chelate; SIL - sodium metalsilicate; DW - dry weight.

Elicitation with a solution containing sodium silicate and Fe-EDTA (SIL-Fe) lowered the content of free (-)-epicatechin in buckwheat sprouts (Table 1). No effect of SIL-Fe was observed in other free flavonoids, except for iso-rhamnetin and vitexin, whose contents increased (Table 2). SIL-Fe had various effects on flavonoid esters. In some of them ((-)-epicatechin, luteolin, apigenin), it inhibited their accumulation, while in others it had no significant effect (Tables 1 and 2). SIL-Fe only favored the accumulation of orientin esters. However, SIL-Fe caused a significant reduction in quercetin and apigenin glycosides, but to a small extent in the glycosides of other flavonoids. In general, SIL-Fe decreased the total content of free flavonoids, as well as their esters and glycosides (Table 3).

Sodium silicate (SIL) caused a decrease in the contents of free (-)-epicatechin, quercetin, iso-rhamnetin, and apigenin, and an increase the contents of orientin, vitexin, and naringenin (Tables 1 and 2). The use of SIL increased also the content of esters of flavonoids, except for luteolin, apigenin, and kaempferol. Moreover, SIL decreased the contents of quercetin glycosides, but increased the contents of luteolin, apigenin, and naringenin glycosides. For total flavonoids, the use of SIL led to a reduction in their free forms and glycosides, but increased their ester content (Table 3).

In contrast to our results, in most studies conducted to date, the use of iron or silicon compounds has increased
TABLE 3. The contents of total flavonols, flavones, and all flavonoids (free and released from ester and $O$-glycoside forms) in buckwheat sprouts $(\mu \mathrm{g} / \mathrm{g} \mathrm{DW})$ treated with elicitors during growth.

\begin{tabular}{l|c|c|c|c}
\hline Treatment & Free form & Esters & O-glycosides & Total \\
\hline \multicolumn{5}{c}{ Total flavonols } \\
\hline Control & $128.8 \pm 4.1^{\mathrm{b}}$ & $97.63 \pm 3.10^{\mathrm{b}}$ & $753.5 \pm 20.1^{\mathrm{a}}$ & $978.0 \pm 27.3^{\mathrm{a}}$ \\
SIL-Fe & $202.6 \pm 6.4^{\mathrm{a}}$ & $81.74 \pm 2.8^{\mathrm{c}}$ & $514.7 \pm 15.3^{\mathrm{b}}$ & $799.0 \pm 24.6^{\mathrm{b}}$ \\
SIL & $84.01 \pm 3.12^{\mathrm{c}}$ & $143.3 \pm 4.3^{\mathrm{a}}$ & $593.7 \pm 15.9^{\mathrm{b}}$ & $821.0 \pm 23.3^{\mathrm{b}}$ \\
\hline & & Total flavones & \\
\hline Control & $190.5 \pm 4.6^{\mathrm{b}}$ & $178.7 \pm 3.9^{\mathrm{b}}$ & $133.6 \pm 3.8^{\mathrm{b}}$ & $502.8 \pm 12.3^{\mathrm{b}}$ \\
SIL-Fe & $214.9 \pm 5.1^{\mathrm{ab}}$ & $196.5 \pm 4.5^{\mathrm{b}}$ & $117.6 \pm 2.9^{\mathrm{b}}$ & $529.0 \pm 12.5^{\mathrm{b}}$ \\
SIL & $241.7 \pm 6.0^{\mathrm{a}}$ & $266.4 \pm 5.8^{\mathrm{a}}$ & $190.6 \pm 4.4^{\mathrm{a}}$ & $698.6 \pm 16.2^{\mathrm{a}}$ \\
\hline & & Total flavonoids & \\
\hline Control & $3851 \pm 66^{\mathrm{a}}$ & $354.6 \pm 8.8^{\mathrm{b}}$ & $888.7 \pm 10.6^{\mathrm{a}}$ & $5094 \pm 85^{\mathrm{a}}$ \\
SIL-Fe & $3095 \pm 25^{\mathrm{b}}$ & $312.8 \pm 8.6^{\mathrm{b}}$ & $637.1 \pm 9.1^{\mathrm{c}}$ & $4044 \pm 43^{\mathrm{c}}$ \\
SIL & $2982 \pm 30^{\mathrm{b}}$ & $543.4 \pm 9.7^{\mathrm{a}}$ & $788.9 \pm 8.6^{\mathrm{b}}$ & $4314 \pm 48^{\mathrm{b}}$ \\
\hline
\end{tabular}

Results are shown as mean \pm standard deviation $(n=3)$. Means marked with the same letter are statistically insignificant at $\mathrm{P}>0.05$ (post hoc Tukey's test). Comparisons were made within each column, for each flavonoid group separately. SIL-Fe - sodium metasilicate and Fe-EDTA chelate; SIL - sodium metalsilicate; DW - dry weight.

the content of phenolic compounds [Fawe et al., 1998; Kidd et al., 2001; Przybysz et al., 2016; Ribera-Fonseca et al., 2018]. However, Chérif et al. [1994] reported that silicon had no effect on phenolic contents of plants. In contrast, Rogalla \& Römeheld [2002] reported a decrease in phenolic content and the activity of phenylalanine ammonia-lyase (PAL) in Si-supplemented plants. These authors suggest that it was due to the formation of silicon-phenol complexes in response to stress. Published data on the effects of Si and Fe concern sprouts and plants of species other than buckwheat, and at different stages of development. Moreover, the methods of Si and Fe application differ from the method used in our study. This makes it difficult to explain the effects of SIL-Fe and SIL in buckwheat sprouts.

Apart from a rich set of flavonoids, the described study of 7-day buckwheat sprouts confirmed the presence of seven phenolic acids (4-hydroxybenzoic, caffeic, sinapic, p-coumaric, ferulic, syringic, and chlorogenic) occurring as free forms, esters, and glycosides (Tables 4 and 5). The quantitatively major phenolic acid in 7-day buckwheat sprouts was 4-hydroxybenzoic acid (Table 4). It occurred in the free form and as esters and glycosides. The bound forms accounted for almost $97 \%$ of its total content. In the case of other acids, they occurred mainly as esters. In our previous study, $o$-, $m$-, and $p$-coumaric acids, sinapic acid, caffeic acid, and two isomers of ferulic acid were found in 11-day buckwheat sprouts [Wiczkowski et al., 2016]. On the other hand, Zhang et al. [2015] detected there gallic, 3,4-dihydroxybenzoic, 2,3,4-trihydroxybenzoic, 4-hydroxybenzoic, chlorogenic, vanillic, caffeic, syringic, $p$-coumaric, ferulic, sinapic, and trans3-hydroxycinnamic acids. However, Park et al. [2017] have 
TABLE 4. The contents of major phenolic acids (free and released from ester and $O$-glycoside forms) in buckwheat sprouts $(\mu \mathrm{g} / \mathrm{g} \mathrm{DW})$ treated with elicitors during growth.

\begin{tabular}{l|c|c|c|c}
\hline Treatment & Free form & Esters & $O$-glycosides & Total \\
\hline Control & $155.3 \pm 2.89^{\mathrm{b}}$ & $628.5 \pm 8.8^{\mathrm{a}}$ & $3635 \pm 28^{\mathrm{a}}$ & $4419 \pm 40^{\mathrm{a}}$ \\
SIL-Fe & $167.1 \pm 1.99^{\mathrm{b}}$ & $325.5 \pm 4.6^{\mathrm{c}}$ & $3183 \pm 18^{\mathrm{b}}$ & $3675 \pm 25^{\mathrm{c}}$ \\
SIL & $211.6 \pm 2.15^{\mathrm{a}}$ & $441.8 \pm 4.4^{\mathrm{b}}$ & $3532 \pm 26^{\mathrm{a}}$ & $4185 \pm 33^{\mathrm{b}}$ \\
\hline \multicolumn{5}{c}{ Caffeic acid } \\
\hline Control & $61.30 \pm 2.66^{\mathrm{b}}$ & $914.8 \pm 13.3^{\mathrm{c}}$ & $85.60 \pm 3.20^{\mathrm{c}}$ & $1062 \pm 19^{\mathrm{c}}$ \\
SIL-Fe & $37.61 \pm 1.89^{\mathrm{c}}$ & $1458 \pm 23^{\mathrm{b}}$ & $186.5 \pm 2.77^{\mathrm{a}}$ & $1682 \pm 28^{\mathrm{b}}$ \\
SIL & $88.72 \pm 3.21^{\mathrm{a}}$ & $1654 \pm 26^{\mathrm{a}}$ & $155.2 \pm 2.44^{\mathrm{b}}$ & $1898 \pm 32^{\mathrm{a}}$ \\
\hline \multicolumn{5}{c}{$p-$ Coumaric acid } \\
\hline Control & $31.34 \pm 1.56^{\mathrm{a}}$ & $354.7 \pm 4.2^{\mathrm{c}}$ & $7.63 \pm 0.66^{\mathrm{c}}$ & $393.6 \pm 6.5^{\mathrm{c}}$ \\
SIL-Fe & $26.74 \pm 1.54^{\mathrm{a}}$ & $487.1 \pm 5.1^{\mathrm{a}}$ & $20.79 \pm 1.25^{\mathrm{a}}$ & $534.6 \pm 7.9^{\mathrm{a}}$ \\
SIL & $33.62 \pm 2.10^{\mathrm{a}}$ & $433.4 \pm 3.9^{\mathrm{b}}$ & $14.10 \pm 1.09^{\mathrm{b}}$ & $481.2 \pm 7.1^{\mathrm{b}}$ \\
\hline \multicolumn{5}{c}{ Sinapic acid } \\
\hline Control & $0.63 \pm 0.11^{\mathrm{a}}$ & $97.47 \pm 3.20^{\mathrm{a}}$ & $20.71 \pm 1.45^{\mathrm{b}}$ & $118.8 \pm 4.8^{\mathrm{a}}$ \\
SIL-Fe & $1.28 \pm 0.22^{\mathrm{a}}$ & $73.75 \pm 2.76^{\mathrm{b}}$ & $22.46 \pm 1.56^{\mathrm{b}}$ & $97.50 \pm 4.6^{\mathrm{a}}$ \\
SIL & $1.26 \pm 0.24^{\mathrm{a}}$ & $74.33 \pm 2.68^{\mathrm{b}}$ & $31.90 \pm 2.09^{\mathrm{a}}$ & $107.5 \pm 5.0^{\mathrm{a}}$
\end{tabular}

Results are shown as mean \pm standard deviation $(n=3)$. Means marked with the same letter are statistically insignificant at $\mathrm{P}>0.05$ (post hoc Tukey's test). Comparisons were made within each column, for each phenolic acid separately. SIL-Fe - sodium metasilicate and Fe-EDTA chelate; SIL - sodium metasilicate; DW - dry weight.

found only gallic, chlorogenic, caffeic, and benzoic acids in these sprouts. In the summary of so different results, it can be seen that many factors used in the production of buckwheat sprouts affect the composition and content of their phenolic compounds. The main factor seems to be the light conditions during the growth of buckwheat sprouts, but also an elicitor and the cultivar used [Horbowicz et al., 2015; Kim et al., 2008; Koyama et al., 2013; Park et al., 2017, 2019; Uddin et al., 2013; Wiczkowski et al., 2014; Zhang et al., 2015].

The application of the SIL-Fe mixture decreased the contents of free $p$-coumaric and caffeic acids, and increased the contents of ferulic, chlorogenic, and sinapic acids (Tables 4 and 5). At the same time, the content of the esters of caffeic, $p$-coumaric, and syringic acids increased, while that of the esters of 4-hydroxybenzoic and sinapic acids decreased tangibly. Both elicitors have led to a considerable increase in the caffeic acid ester content. SIL-Fe also increased the content of glycosides of caffeic, $p$-coumaric and ferulic acids, but decreased the level of 4-hydroxybenzoic acid. In general, SIL-Fe did not affect the total content of free phenolic acids, but increased the level of their esters, and decreased the content of glycosides (Table 5). Elicitation with SIL increased the accumulation of free forms of phenolic acids and their total content (Table 5) as well as the contents of esters and glycosides of most phenolic acids and their total content.
TABLE 5. The contents of minor and total phenolic acids (free and released from ester and $O$-glycoside forms) in buckwheat sprouts $(\mu \mathrm{g} / \mathrm{g}$ DW) treated with elicitors during growth.

\begin{tabular}{lccccc}
\hline Treatment & Free form & Esters & $O$-glycosides & Total \\
\hline \multicolumn{5}{c}{ Ferulic acid } \\
Control & $2.80 \pm 0.09^{\mathrm{a}}$ & $49.74 \pm 1.03^{\mathrm{a}}$ & $1.86 \pm 0.08^{\mathrm{b}}$ & $54.40 \pm 1.20^{\mathrm{a}}$ \\
SIL-Fe & $3.84 \pm 0.07^{\mathrm{a}}$ & $52.13 \pm 1.25^{\mathrm{a}}$ & $4.76 \pm 0.10^{\mathrm{a}}$ & $60.72 \pm 1.42^{\mathrm{a}}$ \\
SIL & $3.17 \pm 0.06^{\mathrm{a}}$ & $51.69 \pm 1.22^{\mathrm{a}}$ & $4.10 \pm 0.11^{\mathrm{a}}$ & $58.96 \pm 1.39^{\mathrm{a}}$ \\
\hline \multicolumn{5}{c}{ Syringic acid } \\
\hline Control & nd $32.73 \pm 1.04^{\mathrm{b}}$ & nd & $32.73 \pm 1.04^{\mathrm{b}}$ \\
SIL-Fe & nd & $43.49 \pm 1.22^{\mathrm{a}}$ & nd & $43.49 \pm 1.22^{\mathrm{a}}$ \\
SIL & nd & $47.03 \pm 1.21^{\mathrm{a}}$ & nd & $47.03 \pm 1.21^{\mathrm{a}}$ \\
\hline \multicolumn{5}{c}{ Chlorogenic acid } \\
\hline Control & $33.86 \pm 1.15^{\mathrm{b}}$ & nd & nd & $33.86 \pm 1.15^{\mathrm{b}}$ \\
SIL-Fe & $53.48 \pm 2.09^{\mathrm{a}}$ & nd & nd & $53.48 \pm 2.09^{\mathrm{a}}$ \\
SIL & $20.94 \pm 0.99^{\mathrm{c}}$ & nd & nd & $20.94 \pm 0.99^{\mathrm{c}}$ \\
\hline \multicolumn{5}{c}{ Total phenolic acids } \\
\hline Control & $285.2 \pm 17.7^{\mathrm{b}}$ & $2078 \pm 24^{\mathrm{c}}$ & $3751 \pm 44^{\mathrm{a}}$ & $6114 \pm 86^{\mathrm{b}}$ \\
SIL-Fe & $290.1 \pm 12.3^{\mathrm{b}}$ & $2440 \pm 27^{\mathrm{b}}$ & $3417 \pm 35^{\mathrm{b}}$ & $6147 \pm 74^{\mathrm{b}}$ \\
\hline SIL & $359.3 \pm 10.1^{\mathrm{a}}$ & $2702 \pm 31^{\mathrm{a}}$ & $3735 \pm 29^{\mathrm{a}}$ & $6799 \pm 70^{\mathrm{a}}$ \\
\hline
\end{tabular}

Results are shown as mean \pm standard deviation $(n=3)$. Means marked with the same letter are statistically insignificant at $\mathrm{P}>0.05$ (post hoc Tukey's test). Comparisons were made within each column, for each phenolic acid and total phenolic acids separately. nd - not detected; SIL-Fe - sodium metasilicate and Fe-EDTA chelate; SIL - sodium metalsilicate; DW - dry weight.

Based on the weight of freeze-dried sprouts, it was calculated that $48 \%$ of the $\mathrm{Fe}$ was absorbed during the soaking of buckwheat sprouts in SIL-Fe, while only 8.1 and $8.6 \%$ of the Si during the soaking in SIL-Fe and SIL, respectively (data not shown). Elicitation with the mixture of SIL-Fe decreased the contents of calcium, potassium, sodium, copper, and zinc in buckwheat sprouts (Table 6). Similarly, in a pot experiment with increased levels of silicon in soil, a significant decline was found for calcium, copper, and zinc contents in leaf blades of common reed [Brackhage et al., 2013]. Si present in the nutrient solution diminished the uptake of $\mathrm{Ca}$ by rice, and $\mathrm{Zn}$ content in maize [Kaya et al., 2009; Ma \& Takahashi, 1993]. However, a complex study by Greger et al. [2018] showed that $\mathrm{Si}$ increased the uptake of $\mathrm{Mg}, \mathrm{Ca}, \mathrm{Fe}$, and $\mathrm{Mn}$; and decreased the uptake of $\mathrm{Cu}, \mathrm{Zn}$, and $\mathrm{K}$ from the solution. Furthermore, the transport of $\mathrm{Mg}, \mathrm{Ca}, \mathrm{Mn}$, and Mo to shoot increased, but that of $\mathrm{Fe}, \mathrm{Cu}$, and $\mathrm{Zn}$ decreased, while that of $\mathrm{K}, \mathrm{P}$, and $\mathrm{B}$ was not affected. These authors pointed out that Si influence depended on species examined, as well as conditions of its growth [Greger et al., 2018]. The specificity of the experiment described here differs from other such studies on the influence of Si and $\mathrm{Fe}$ on plants. The seeds and then buckwheat sprouts were soaked in SIL-Fe and SIL solutions for $15 \mathrm{~min}$ in the morning and in the evening. This treatment might have caused some losses of minerals and phytochemicals from 
TABLE 6. The contents of chosen macro- and microelements in buckwheat sprouts $(\mu \mathrm{g} / \mathrm{g} \mathrm{DW})$ treated with elicitors during growth.

\begin{tabular}{|c|c|c|c|c|}
\hline & & Control & SIL-Fe & SIL \\
\hline \multirow{5}{*}{ 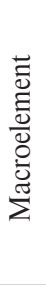 } & Calcium & $1338 \pm 28^{a}$ & $920.6 \pm 12.5^{b}$ & $942.0 \pm 12.1^{\mathrm{b}}$ \\
\hline & Magnesium & $5068 \pm 54^{b}$ & $4919 \pm 45^{b}$ & $5506 \pm 29^{a}$ \\
\hline & Potassium & $10304 \pm 123^{\mathrm{a}}$ & $9407 \pm 98^{b}$ & $9135 \pm 66^{\mathrm{b}}$ \\
\hline & Phosphorus & $14522 \pm 125^{\mathrm{a}}$ & $13883 \pm 134^{a}$ & $13575 \pm 129^{a}$ \\
\hline & Sodium & $1427 \pm 27^{b}$ & $760.5 \pm 18.9^{c}$ & $2865 \pm 39^{a}$ \\
\hline \multirow{5}{*}{ 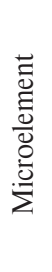 } & Copper & $41.55 \pm 1.26^{\mathrm{a}}$ & $21.72 \pm 0.99^{\mathrm{b}}$ & $22.85 \pm 1.05^{\mathrm{b}}$ \\
\hline & Silicon & $152.6 \pm 8.8^{\mathrm{b}}$ & $464.2 \pm 13.3^{\mathrm{a}}$ & $481.2 \pm 12.9^{\mathrm{a}}$ \\
\hline & Iron & $81.12 \pm 1.89^{b}$ & $353.0 \pm 8.8^{\mathrm{a}}$ & $76.08 \pm 1.77^{b}$ \\
\hline & Zinc & $120.5 \pm 4.1^{\mathrm{a}}$ & $98.39 \pm 1.66^{\mathrm{b}}$ & $95.55 \pm 1.25^{\mathrm{b}}$ \\
\hline & Manganese & $53.74 \pm 1.51^{b}$ & $60.87 \pm 1.24^{\mathrm{ab}}$ & $66.40 \pm 1.44^{\mathrm{a}}$ \\
\hline
\end{tabular}

Results are shown as mean \pm standard deviation $(n=3)$. Means marked with the same letter are statistically insignificant at $\mathrm{P}>0.05$ (post hoc Tukey's test). Comparisons were made within each row, for each macroand microelement separately. SIL-Fe - sodium metasilicate and Fe-EDTA chelate; SIL - sodium metasilicate; DW - dry weight.

soaked tissues. Therefore, discussion with data presented by other researchers is difficult.

The use of SIL-Fe has doubled the silicon content and more than five times the iron content of buckwheat sprouts. As a result of this procedure, the ratio of total flavonoids to iron content decreased from 64 in control sprouts to 11 in the SIL-Fe treated ones. In comparison, the use of silicate alone (SIL) also reduced the calcium, potassium, copper, and zinc contents, but increased magnesium and sodium contents, and almost doubled the silicon content. According to previous studies, a high level of flavonoids can inhibit intestinal absorption of the nonheme type of iron [Kim et al., 2008; Thankachan et al., 2008; Zijp et al., 2000]. Therefore, it seems that a significant change in the flavonoid-iron ratio is beneficial for the bioavailability of plant-derived Fe.

\section{CONCLUSION}

The results of the study indicate that it is possible to produce buckwheat sprouts with a high content of flavonoids and fortified with iron. The research carried out showed also that the mixture of sodium silicate (SIL) and iron chelate (SIL-Fe) influenced the accumulation of individual phenolics in buckwheat sprouts in different ways. Among the major flavonoids of the SIL-Fe-treated buckwheat sprouts, the contents of free forms and esters of (-)-epicatechin and glycosides of quercetin significantly decreased. The reduction of the major flavonoids caused the total content of flavonoids to decrease as well. As a result, the ratio of total flavonoids to iron content decreased from 64 in control sprouts to 11 in the SIL-Fe treated ones. To the best of our knowledge, this is the first work which describes the influence of iron chelate and sodium metasilicate on the content of phenolic compounds and minerals in sprouts of common buckwheat.

\section{RESEARCH FUNDING}

This research was partly supported by the statutory funds (72/20/B) of the Institute of Biological Sciences, Siedlce University of Natural Sciences and Humanities, Poland.

\section{CONFLICT OF INTEREST}

The authors declare no conflict of interest.

\section{ORCID IDs}

H. Dębski https://orcid.org/0000-0002-4145-1102

M. Horbowicz https://orcid.org/0000-0002-1789-4034

D. Szawara-Nowak https://orcid.org/0000-0003-2326-065X

W. Wiczkowski https://orcid.org/0000-0001-6021-5589

\section{REFERENCES}

1. Baenas, N., García-Viguera, C., Morena, D.A. (2014). Elicitation: a tool for enriching the bioactive composition of foods. Molecules, 19, 13541-13563.

https://doi.org/10.3390/molecules190913541

2. Barnes, K.W., Debrah, E. (1997). Determination of nutrition labeling education act minerals in food by inductively coupled plasma-optical emission spectrometry. Atomic Spectroscopy, 18, $41-54$.

3. Benincasa, P., Falcinelli, B., Lutts, S., Stagnari, F., Galieni, A. (2019). Sprouted grains: a comprehensive review. Nutrients, $11(2)$, art. no. 421.

https://doi.org/10.3390/nu11020421

4. Brackhage, C., Schaller, J., Bäucker, E., Dudel, E.G. (2013). Silicon availability affects the stoichiometry and content of calcium and micro nutrients in the leaves of common reed. Silicon, 5, 199-204.

https://doi.org/10.1007/s12633-013-9145-3

5. Cappellini, M.D., Musallam, K.M., Taher, A.T. (2020). Iron deficiency anaemia revisited. Journal of Internal Medicine, 287(2), 153-170.

https://doi.org/10.1111/joim.13004

6. Chérif, M., Asselin, A., Belanger, R.R. (1994). Defense responses induced by soluble silicon in cucumber roots infected by Pythium spp. Phytopathology, 84, 236-242.

https://doi.org/10.1094/Phyto-84-236

7. Cory, H., Passarelli, S., Szeto, J., Tamez, M., Mattei, J. (2018). The role of polyphenols in human health and food systems: a mini-review. Frontiers in Nutrition, 5, art. no. 87.

https://doi.org/10.3389/fnut.2018.00087

8. Cvejic, H.J., Russo, G., Godos, J., Mimica-Dukić, N., Simin, N., Bjelica, A., Grosso, G. (2018). Beneficial effects of polyphenols on chronic diseases and ageing. In: Galanakis CM, ed., Polyphenols: Properties, Recovery, and Applications. Amsterdam, The Netherlands: Elsevier Inc., pp. 69-102. https://doi.org/10.1016/B978-0-12-813572-3.00003-8

9. Fawe, A., Abou-Zaid, M., Menzies, J.G., Bélanger, R.R. (1998). Silicon-mediated accumulation of flavonoid phytoalexins in cucumber. Phytopathology, 88, 396-401.

https://doi.org/10.1094/PHYTO.1998.88.5.396 
10. Greger, M., Landberg, T., Vaculik, M. (2018). Silicon influences soil availability and accumulation of mineral nutrients in various plant species. Plants, 7, art. no. 41.

https://doi.org/10.3390/plants7020041

11. Gutiérrez-Salmeán, G., Ortiz-Vilchis, P., Vacaseydel, C.M., Rubio-Gayosso, I., Meaney, E., Villarreal, F., Ramírez-Sánchez, I., Ceballos, G. (2014). Acute effects of an oral supplement of (-)-epicatechin on postprandial fat and carbohydrate metabolism in normal and overweight subjects. Food \& Function, 5(3), 521-527. https://doi.org/10.1039/c3fo60416k

12. Horbowicz, M., Wiczkowski, W., Szawara-Nowak, D., Sawicki, T., Kosson, R., Sytykiewicz, H. (2015). The level of flavonoids and amines in de-etiolated and methyl jasmonate treated seedlings of common buckwheat. Phytochemistry Letters, 13, 15-19. https://doi.org/10.1016/j.phytol.2015.05.011

13. Hurrell, R.F., Reddy, M., Cook, J.D. (1999). Inhibition of nonhaem iron absorption in man by polyphenolic-containing beverages. British Journal of Nutrition, 81 (4), 289-295. https://doi.org/10.1017/S0007114599000537

14. Kaya, C., Tuna, A.L., Sonmez, O., Ince, F., Higgs, D. (2009). Mitigation effects of silicon on maize plants grown at high zinc. Journal of Plant Nutrition, 32, 1788-1798. https://doi.org/10.1080/01904160903152624.

15. Kidd, P.S., Llugany, M., Poschenrieder, C.H., Gunse, B., Barcelo, J. (2001). The role of root exudates in aluminium resistance and silicon-induced amelioration of aluminium toxicity in three varieties of maize (Zea mays L.). Journal of Experimental Botany, 52, 1339-1352.

https://doi.org/10.1093/jexbot/52.359.1339

16. Kim, E.Y., Ham, S.K., Shigenaga, M.K., Han, O. (2008). Bioactive dietary polyphenolic compounds reduce nonheme iron transport across human intestinal cell monolayers. Journal of Nutrition, 138(9), 1647-1651.

https://doi.org/10.1093/jn/138.9.1647

17. Kim, S.-J., Zaidul, I. S. M., Suzuki, T., Mukasa, Y., Hashimoto, N., Takigawa, S., Noda, T., Matsuura-Endo, C., Yamauchi, H. (2008). Comparison of phenolic compositions between common and tartary buckwheat (Fagopyrum) sprouts. Food Chemistry, 110, 814-820.

https://doi.org/10.1016/j.foodchem.2008.02.050

18. Kim, S.-L., Kim, S.-K., Park, C.-H. (2004). Introduction and nutritional evaluation of buckwheat sprouts as a new vegetable. Food Research International, 37, 319-327. https://doi.org/10.1016/j.foodres.2003.12.008

19. Koyama, M., Nakamura, C., Nakamura, K. (2013). Changes in phenols contents from buckwheat sprouts during growth stage. Journal of Food Science and Technology, 50(1), 86-93. https://doi.org/10.1007/s13197-011-0316-1

20. Kreft, M. (2016). Buckwheat phenolic metabolites in health and disease. Nutrition Research Reviews, 29, 30-39. https://doi.org/10.1017/S0954422415000190

21. Ma, Q., Kim, E.Y., Lindsay, E.A., Han, O. (2011). Bioactive dietary polyphenols inhibit heme iron absorption in a dose-dependent manner in human intestinal Caco-2 cells. Journal of Food Science, 76(5), H143-H150. https://doi.org/10.1111/j.1750-3841.2011.02184.x

22. Ma, J.F., Takahashi, E. (1993). Interaction between calcium and silicon in water-cultured rice plants. Plant Soil, 148, 107-113. https://doi.org/10.1007/BF02185390
23. Marschner, H. (1995). Mineral Nutrition of Higher Plants. 2nd Edition. Academic Press. London. Chapter 4. Uptake and Release of Mineral Elements by Leaves and Other Aerial Plant Parts. pp. 116-130.

https://doi.org/10.1016/B978-012473542-2/50006-7

24. Mbithi-Mwikya, S., Van Camp, J., Yiru, Y., Huyghebaert, A. (2000). Nutrient and antinutrient changes in finger millet (Eleusine coracan) during sprouting. LWT - Food Science and Technology, 33, 9-14.

https://doi.org/10.1006/fstl.1999.0605

25. Park, C.H., Yeo, H.J., Park, Y.J., Morgan, A.M., Valan Arasu, M., Al.-Dhabi, N.A., Park, S.U. (2017). Influence of indole-3-acetic acid and gibberellic acid on phenylpropanoid accumulation in common buckwheat (Fagopyrum esculentum Moench) sprouts. Molecules, 22(3), art. no. 374.

https://doi.org/10.3390/molecules22030374

26. Park, C.H., Yeo, H.J., Park, Y.E., Chun, S.W., Chung, Y.S., Lee, S.Y., Park, S.U. (2019). Influence of chitosan, salicylic acid and jasmonic acid on phenylpropanoid accumulation in germinated buckwheat (Fagopyrum esculentum Moench). Foods, 8(5), art. no. 153. https://doi.org/10.3390/foods8050153

27. Płatosz, N., Sawicki, T., Wiczkowski, W. (2020). Profile of phenolic acids and flavonoids of red beet and its fermentation products. Does long-term consumption of fermented beetroot juice affect phenolics profile in human blood plasma and urine? Polish Journal of Food and Nutrition Sciences, 70(1), 55-65. https://doi.org/10.31883/pjfns/116613

28. Przybysz, A., Wrochna, M., Małecka-Przybysz, M., Gawrońska, H., Gawroński, S.W. (2016). Vegetable sprouts enriched with iron: Effects on yield, ROS generation and antioxidative system. Scientia Horticulturae, 203, 110-117.

https://doi.org/10.1016/j.scienta.2016.03.017

29. Ribera-Fonseca, A., Rumpel, C., Mora de la Luz, M., Nikolic, M., Cartes, P. (2018). Sodium silicate and calcium silicate differentially affect silicon and aluminium uptake, antioxidant performance and phenolics metabolism of ryegrass in an acid Andisol. Crop and Pasture Science 69, 205-215.

https://doi.org/10.1071/CP17202

30. Rogalla, H., Römeheld, V. (2002). Effects of silicon on the availability of boron: Possible effects on the phenol pathway and on the redox status in Cucumis sativus L. In: Goldbach, H.E., Rerkasem, B., Wimmer, M.A., Brown, P.H., Thellier, M. Bell, R.W. Boron in Plant and Animal Nutrition. Kluwer Academic/Plenum New York, pp. 205-213.

31. Ruiz-Garcia, Y., Gómez-Plaza, E. (2013). Elicitors: a tool for improving fruit phenolic content. Agriculture, 3, 33-52. https://doi.org/10.3390/agriculture3010033

32. Santhakumar, A., Battino, M., Alvarez-Suarez, J. (2018). Dietary polyphenols: structures, bioavailability and protective effects against atherosclerosis. Food and Chemical Toxicology, 113, 49-65.

https://doi.org/10.1016/j.fct.2018.01.022

33. Simos, Y.V., Verginadis, I.I., Toliopoulos, I.K., Velalopoulou, A.P., Karagounis, I.V., Karkabounas, S.C., Evangelou, A.M. (2012). Effects of catechin and epicatechin on superoxide dismutase and glutathione peroxidase activity, in vivo. Redox Report: Communications in Free Radical Research, 17(5), 181-186. https://doi.org/10.1179/1351000212Y.0000000020 
34. Sokrab, A.M., Ahmed, I.A.M., Babiker, E.E. (2012). Effect of germination on antinutritional factors, total, and extractable minerals of high and low phytate corn (Zea mays L.) genotypes. Journal of the Saudi Society of Agricultural Sciences, 11, 123-128. https://doi.org/10.1016/j.jssas.2012.02.002

35. Stoltzfus, R.J., Mullany, L.C., Black, R.E. (2004). Iron deficiency anaemia. Chapter 4 in: Ezzati M., Lopez A.D., Rodgers A.A., Murray C.J.L., Editors. Comparative Quantification of Health Risks: Global and Regional Burden of Disease Attributable to Selected Major Risk Factors. World Health Organization. Geneva. Vol. 1., pp. 163-210.

36. Terpinc, P., Cigić, B., Polak, T., Hribar, J., Požrl, T. (2016). LC-MS analysis of phenolic compounds and antioxidant activity of buckwheat at different stages of malting. Food Chemistry, 210, 9-17. https://doi.org/10.1016/j.foodchem.2016.04.030

37. Thankachan, P., Walczyk, T., Muthayya, S., Kurpad, A.V., Hurrell, R.F. (2008). Iron absorption in young Indian women: the interaction of iron status with the influence of tea and ascorbic acid. American Journal of Clinical Nutrition, 87(4), 881-886. https://doi.org/10.1093/ajcn/87.4.881

38. Uddin, M.R., Li, X., Park, W.T., Kim, Y.B., Kim, S.J., Kim, Y.S., Lee, M.Y., Park, C.H., Park, S.U. (2013). Phenolic compound content in different organs of Korean common buckwheat cultivars. Asian Journal of Chemistry, 25(1), 424-426. https://doi.org/10.14233/ajchem.2013.13141

39. Watanabe, M. (1998). Catechins as antioxidants from buckwheat (Fagopyrum esculentum Moench) groats. Journal of Agricultural and Food Chemistry, 46, 839-845.

https://doi.org/10.1021/jf9707546
40. Wijngaard, H.H., Arendt, E.K. (2006). Buckwheat. Cereal Chemistry Journal, 83, 391-401.

https://doi.org/10.1094/CC-83-0391

41. Wiczkowski, W., Szawara-Nowak, D., Dębski, H., Mitrus J., Horbowicz, M. (2014). Comparison of flavonoids profile in sprouts of common buckwheat cultivars and wild tartary buckwheat. International Journal of Food Science and Technology, 49, 1977-1984.

https://doi.org/10.1111/ijfs.12484

42. Wiczkowski, W., Szawara-Nowak, D., Sawicki, T., Mitrus, J., Kasprzykowski, Z., Horbowicz, M. (2016). Profile of phenolic acids and antioxidant capacity in organs of common buckwheat sprout. Acta Alimentaria, 45, 250-257.

https://doi.org/10.1556/066.2016.45.2.12

43. Zhang, G., Xu, Z., Gao, Y., Huang, X., Zou, Y., Yang, T. (2015). Effects of germination on the nutritional properties, phenolic profiles, and antioxidant activities of buckwheat. Journal of Food Science, 80, H1111-H1119.

https://doi.org/10.1111/1750-3841.12830

44. Zijp, I.M., Korver, O., Tijburg, L.B. (2000). Effect of tea and other dietary factors on iron absorption. Critical Reviews in Food Science and Nutrition, 40(5), 371-398.

https://doi.org/10.1080/10408690091189194

Submitted: 13 July 2020. Revised: 16 October and 20 November 2020. Accepted: 1 December 2020. Published on-line: 22 January 2021. 